\title{
Introduction: The Temporal Turn in Eighteenth-Century Studies
}

\author{
Jesse Molesworth \\ Indiana University
}

We are confounded and perplexed about time.

-Bishop George Berkeley, private correspondence (1730) ${ }^{1}$

The leading idea which is present in all our researches, and which accompanies every fresh observation ... is-

Time!_Time! —-Time!

-George Poulett Scrope, Memoir on the Geology of Central France (1827)

Two quotations, similar in spirit but separated by nearly a century. In the first, George Berkeley, Bishop of Cloyne, ruminates on what was perhaps the fundamental scholarly question of his day, the distinction between the timelessness of God and the time-bound, tense-ruled domain of humans. In the second, the volcanologist George Poulett Scrope ruminates on what was perhaps the fundamental scholarly question of his day, reckoning the geological age of the Earth, the discovery of which threatened to annul the distinction employed by Berkeley. Indeed, for Scrope the study of time was both "important" and "humiliating": important because the finitude of time implied a new understanding of nature, humiliating because the vastness of time implied the smallness of human history and, consequently, the self. ${ }^{3}$ We are but "trifles in the calendar of Nature," Scrope would write, seemingly echoing Henry Fielding's well-known remarks on the nature of fiction: that empty periods of narration were to be considered "as blanks in the grand lottery of time."4

Both Berkeley's and Scrope's quotations might apply to the current moment in eighteenth-century scholarship. Consider Tita Chico's recent remark in a review essay of books by Jessica Riskin, Christina Lupton, and Amit S. Yahav: "The Enlightenment staged myriad scientific, technological, and print revolutions, resulting in experiences of time that shaped who and what we thought we could be." 5 This theme-the connection between the Enlightenment and 
temporality - has been explored in any number of recent conferences and symposia. In June 2014, for example, the Newberry Library in Chicago convened a one-day symposium called "Reading Time," devoted to topics like imperial time, the physics and physiology of time, and the mediation of time during the eighteenth century. In May 2016, the Bloomington Center for EighteenthCentury Studies convened a three-day workshop called "Eighteenth-Century Futures," devoted to topics like slow time, speculative time, and the connection between time and space during the eighteenth century. In September 2016, the English Institute convened its seventy-fifth annual meeting in Chicago, devoted to the topic "Time." While not focused exclusively on any historical period, the conference selected as its shared "theory text" E. P. Thompson's essay, "Time, Work-Discipline, and Industrial Capital"—suggesting, perhaps, that the topic is best understood against the backdrop of Thompson's observations on the connection between industrial labor and the rise of modern timekeeping technology during the eighteenth century. ${ }^{6}$

Or consider Karol Berger's claim that musical form in Europe "became primarily temporal" by the end of the eighteenth century. ${ }^{7}$ Whereas earlier musicians and composers (Johann Sebastian Bach, to take one prominent example) understood musical composition as primarily cyclical in structure, the modern triumvirate of Franz Joseph Haydn, Wolfgang Amadeus Mozart, and Ludwig van Beethoven authored a shift in musical architecture:

In the later eighteenth century European art music began to take seriously the flow of time from past to future. Until then music was simply "in time"; it "took time"-events had somehow to be arranged successively, but the distinction between past and future, "earlier" and "later," mattered little to the way the music was experienced and understood. From that point on music added the experience of linear time, of time's arrow, to its essential subject matter. Music could no longer be experienced with understanding unless one recognized the temporal ordering of events. ${ }^{8}$

Thus cyclical or repetitious forms, such as the fugue, faded in importance. In their place arose directional forms, such as the sonata and the symphony, both of which rely on the temporal progression of four contrasting movements.

Artists as diverse as Haydn, Mozart, and Beethoven therefore seem to have capitalized on newer expressions of directional time promoted throughout the eighteenth century and beyond. Berger's sense of the movement from "Bach's cycle" to "Mozart's arrow," for instance, looks much like the project embraced by William Hogarth in Britain throughout the 1730s and 1740s. In graphic works like A Harlot's Progress (1731), A Rake's Progress (1735), The Four Times of Day (1738), and Marriage à-la-Mode (1743-45), Hogarth sought-quite explicitly - to translate cycle into progress, replacing an older sense of time, in which images gain meaning when understood within the timeless context of 
Christian and classical iconography, with a newer sense of time, in which images gain meaning when understood consecutively and chronologically. ${ }^{9}$ This observation, in turn, looks much like Ian Watt's well-known evaluation of the temporality of the realist novel: "The novel's plot is also distinguished from most previous fiction by its use of past experience as the cause of present action: a causal connection operating through time replaces the reliance of earlier narratives on disguises and coincidences, and this tends to give the novel a much more cohesive structure." 10

For Watt the temporality of the novel descended from the philosophical empiricism of John Locke and David Hume, who wrote of individual identity as molded by the accumulation of experience. For more recent critics like Sandra Macpherson, the consequentialism of novelists like Daniel Defoe, Samuel Richardson, Fielding, and Jane Austen expresses the consequentialism of larger cultural movements like the rise of modern liability law and estate law. ${ }^{11}$ But when seen in the light of Berger's thesis, both Watt and Macpherson offer a tantalizing prospect: the prospect of viewing works like The Harlot's Progress or Fielding's Tom Jones (1749) as early expressions of the temporality of Beethoven's Ninth Symphony (1824). Or, to phrase things slightly differently: one might see the tripartite arrangement of Tom Jones as symphonic in structurefundamentally temporal in its organization-rather than as "Palladian," as it has often been described. ${ }^{2}$

As Roger Matthew Grant has shown, the shift in musical form described by Berger was subtended by a shift in the very measurement of musical time. Earlier musical theorists such as Gioseffo Zarlino, Johannes Lippius, and Étienne Loulié all conceptualized time principally through the Aristotelian concept of motus, or motion. Thus, musical rhythm - the "beat" - typically connoted physical movement, especially the movement of the hand or the beating of the heart. During the eighteenth century, however, a shift occurred:

The eighteenth century's multiplicity of measures shifted the focus of explanation away from the physical implementation of the beat onto the relationship between timekeeping and notation. This change in meter's theorization came alongside a rethinking of time, in which natural philosophy began to conceptualize time as a quantity entirely independent of earthly motions and physical changes. At the end of century and into the nineteenth, theorists were able to describe meter as a way of measuring the unending progression of homogeneous, "absolute" time, and offered a universal theory of measurement that would account for any of the meters they described. ${ }^{13}$

Musical form thus followed the revolution in timekeeping described variously by Thompson, David Landes, and Stuart Sherman. ${ }^{14}$ Nothing concretized this revolution in musical time more than the widespread adoption of the metronome, the mechanical device used to keep time introduced by Johann Maelzel in 1815 and championed immediately by Beethoven. 
Grant's reference to "absolute" time as "homogenous" of course invokes Walter Benjamin's well-known description of historical time..$^{15}$ Yet it is worth noting that "absolute" time was understood differently within the eighteenth century. Isaac Newton's Principia (1687), for example, relies on the following distinction between "absolute" time and "common" time:

\begin{abstract}
Absolute, true, and mathematical time, in and of itself and of its own nature, without reference to anything external, flows uniformly and by another name is called duration. Relative, apparent, and common time is any sensible and external measure (precise or imprecise) of duration by means of motion; such a measurefor example, an hour, a day, a month, a year-is commonly used instead of true time. ${ }^{16}$
\end{abstract}

Newton's distinction would be adopted throughout the eighteenth century in a variety of contexts, for example in widely circulated textbooks by the clergyman William Holder and by the chronologist James Hodgson. ${ }^{17}$ For those living in the eighteenth century, that is, the crucial division rested not in competing senses of historical time but in an emergent distinction between abstract time (Newtonian "absolute" time) and measured time ("common" time).

Indeed, in the wake of Newton's influence, history itself became subjected to new techniques of scale and measurement. As Daniel Rosenberg and Anthony Grafton have compellingly shown, the modern timeline dates to the middle decades of the eighteenth century, especially to the chronographic charts developed by the English scientist and theologian Joseph Priestley. Rather than simply arranging historical events in their proper order, in the manner of traditional chronologies, Priestley sought, in graphic devices like his 1765 Chart of Biography and in his 1769 New Chart of History, to render time in its proper proportion as well. Such charts contributed to a fundamental shift in the perception of historical time:

\footnotetext{
It was not until the middle of the eighteenth century that a common visual vocabulary for time maps caught on. But the new linear formats of the eighteenth century were so quickly accepted that, within decades, it was hard to remember a time when they were not already in use. The key problem in chronographics, it turned out, was not how to design more complex visual schemes-the approach of many would-be innovators in the seventeenth century-but, rather, how to simplify, how to create a visual scheme to clearly communicate the uniformity, directionality, and the irreversibility of historical time. ${ }^{18}$
}

Directly inspired by Newton, Priestley's timelines were, therefore, emanations of the directional temporality we have seen at work in Hogarth, Fielding, Beethoven, and others. The rise of the visual metaphor of historical time as a line 
represents, simultaneously, the decline of the metaphor of history as cyclical, seen prominently in the earlier works of chronologists like Joseph Justus Scaliger and James Ussher, to name just a few. ${ }^{19}$

This does not, of course, imply that other conceptions of time have become unthinkable. For Julia Kristeva, to take one prominent example, "women's time" has been traditionally defined against the linear (masculine) time of dialectical movement:

Female subjectivity would seem to provide a specific measure that essentially retains repetition and eternity from among the multiple modalities of time known through the history of civilizations. . . There are cycles, gestation, the eternal recurrence of a biological rhythm which conforms to that of nature and imposes a temporality whose stereotyping may shock, but whose regularity and unison with what is experienced as extrasubjective time, cosmic time, occasion vertiginous visions and unnamable jouissance. ${ }^{20}$

The maverick philosopher Michel Serres similarly rejects the directional view of time as misguided and arrogant:

Time is paradoxical; it folds or twists; it is as various as the dance of flames in a brazier-here interrupted, there vertical, mobile, and unexpected.

The French language in its wisdom uses the same word for weather and time, le temps. At a profound level they are the same thing. Meteorological weather, predictable and unpredictable, will no doubt some day be explainable by complicated notions of fluctuations, strange attractors. . . . Some day we will perhaps understand that historical time is even more complicated. ${ }^{21}$

Still, it is worth noting that each of these statements comes with a major disclaimer. For Kristeva, the multiple temporalities associated with female subjectivity are so different from directional time that "the very word 'temporality' hardly fits." 22 Serres's final sentence, above, is equally telling: rather than expecting to persuade readers in the present, he seeks, oddly enough, to be vindicated by readers "some day" in the future. To the modern reader, Serres's theory, in which time fluctuates turbulently like the weather, can only be described as unorthodox.

One might therefore see the orthodoxy of directional time, described elsewhere by Johannes Fabian as "imperial time," as one of the principal legacies of eighteenth-century thought. ${ }^{23}$ It is, after all, an assumption shared not simply by those living in the eighteenth century, in the progressivism of Nicholas de Condorcet, for instance, or in the Scottish Enlightenment historiography of William Robertson, Hume, and Adam Ferguson. ${ }^{24}$ More than this, its explicit anti-cyclicality undergirds most modern conceptions of historical movement, from the dialectics of Georg Wilhelm Friedrich Hegel and Karl Marx in the 
nineteenth century, to the paradigm shifts of Michel Foucault and Thomas Kuhn in the twentieth, to the actor networks of Bruno Latour in the twentyfirst. As many have noted, Immanuel Kant's 1784 definition of "Enlightenment" (Aufklärung) focuses on process-progression mediated by time-rather than product: "Enlightenment is man's exit from his self-imposed minority." 25 Kant therefore stages Enlightenment itself as a Bildungsroman, the irreversible temporal movement from "darkness" to "light," or from infancy to childhood to adulthood.

On the one hand, then, modern conceptions of temporality, such as we have seen, contributed to an extraordinary strain of Whiggish positivism, epitomized perhaps in Louis-Sébastien Mercier's bestselling fiction of 1771, L'An 2440 (The Year 2440). Mercier's work is sometimes seen as radical or "pioneering," since it was the first fictional work set predominantly in the future. ${ }^{26}$ But it is better seen as a translation of the Renaissance concept of utopia, set not elsewhere but else-when. Unlike Sir Thomas More's utopia, Mercier's futuristic vision of Paris-in which Versailles lies in ruins and the Bastille has been demolished in favor of a Temple of Clemency - was hardly "nowhere." Rather, Mercier viewed it as a concrete eventuality: a prediction of things to come. When the actual Bastille fell, soon enough, on July 14, 1789, Mercier saw it less as an uncanny coincidence and more as a confirmation of his own canny foresight: "Never, I dare say, did a prediction come closer to an event, nor did one give a more detailed account of an astonishing series of transformations. I am therefore the true prophet of the French Revolution." 27

On the other hand, directional time also contributed equally to a growing sense of pessimism and uncertainty about the future. Critics like Emily Rohrbach, Anahid Nersessian, and Jonathan Sachs have recently sought to stage Romanticism, especially in its British context, as a confrontation with the future of limitless possibilities described by Reinhart Koselleck. ${ }^{28}$ Others, like Eric Gidal and Tobias Menely, have sought to connect such pessimism and uncertainty to ecological concerns. ${ }^{29}$ For Menely, for example, William Cowper's georgic poem, The Task: A Poem in Six Books (1785), offers a grand meditation on ecological collapse, prompted by the environmental disturbances spurred by the eruption of the Icelandic volcano Laki in June 1783. While rooted in the material world, Cowper's sense of the "present obfuscation" nevertheless manifests a more profound sense of temporal disturbance:

The "present obfuscation" becomes a figural crux for a host of temporal-epistemic conditions, of which the strange weather of a volcanogenic climate is only one. The Enlightenment division of knowledge separates weather from history, even as it generates a kind of unreadable human atmosphere; providential and eschatological explanations lose their force; seasonal experience, and thus the memory encoded in climatic periodicity, is attenuated; new modes of energy production 
and their environmental consequences outscale modes of representation; and time itself appears to pass, to dissipate, even faster. ${ }^{30}$

Within The Task, therefore, Cowper translates a Benjaminian sense of messianic Jetztzeit into its climatic equivalent, finding signs of an apocalyptic end of time within the natural world. It is part prophecy, channeling a poetic tradition involving figures as diverse as Alexander Pope, William Blake, and Friedrich Hölderlin. But it is simultaneously part prediction, channeling a scientific tradition involving figures as diverse as Blaise Pascal; Georges-Louis Leclerc, Comte de Buffon; and Pierre-Simon Laplace. ${ }^{31}$

The larger point-one hopefully demonstrated by this introduction-is that temporality has emerged as a favored topic for interdisciplinary research on the long eighteenth century. All of the essays collected in this volume bear on this critical movement, just as they bear on the various contours of temporality described above: Scrope's deep time, Beethoven's symphonic time, Hogarth's sequential time, Newton's absolute time, Maelzel's metronomic time, Priestley's proportional time, Mercier's utopian time, and Cowper's apocalyptic time. For example, Michael Nicholson's essay, "Fugitive Pieces: Walpole, Byron, and Queer Time," explores a queer poetics of delay and disruption within two similarly titled works, Horace Walpole's volume of juvenilia, Fugitive Pieces in Verse and Prose (1758), and an early collection of George Gordon, Lord Byron, entitled Fugitive Pieces (1806). For both writers, the idea of the "fugitive piece" enabled access to a temporality of improvisation and anachronism, one standing outside of the "imperial time" of chrononormativity. Amit Yahav's essay, "Leisure Reading and Austen's Case for Differentiated Time," takes up what Michel de Certeau once described as the "great forgetting": the temporal compression produced by the absorptive practice of reading, especially reading novels. In contrast to Joseph Addison, Laurence Sterne, and Denis Diderot, all of whom sought variously to describe this phenomenon, Jane Austen devotes her novel Northanger Abbey (1817) to a trenchant criticism of absorptive reading practices, seeking instead to promote a more disciplined sense of "differentiated time." Jonathan Sachs's essay, "Eighteenth-Century Slow Time: Seven Propositions," offers an antidote to recent attempts to locate a culture of slowness within the present. Rather, as demonstrated in a reading of Cowper's images of quiet repose within The Task, slowness emerges from and against a network of forces-especially the market, print media, and the cultural querelle between the ancients and the moderns-given modern expression during the long eighteenth century. Finally, Michael Cooperson's essay, "Mercier's Carriages: Time Travel's Primal Scene," examines the persistence of carriages, coaches, and automobiles within time-travel narratives from Mercier's $L^{\prime} A n$ 2440 to Robert Zemeckis's film Back to the Future (1985). In a variety of contexts, including non-Western sources like Iranian television, Turkish film, and 
Egyptian fiction, carriage travel encodes Mercier's own temporal progressivism, reconfigured most frequently into the progressive politics of neoliberalism.

No doubt many additional topics, figures, and critics might be subscribed to the temporal turn in eighteenth-century studies. This volume is comprehensive in its concerns but certainly not encyclopedic. Rather, the intent here is to offer both an introduction and an encouragement to the possibilities afforded by this critical turn.

\section{NOTES}

1. George Berkeley, private correspondence, March 24, 1730, in The Works of George Berkeley, Bishop of Cloyne, 9 vols., ed. A. A. Luce and T. E. Jessop (London, 1948-57), 2:293-94, 293. For more on this quotation, see H. Scott Hestevold, "Berkeley's Theory of Time," History of Philosophy Quarterly, 7 no. 2 (1990): 179-92.

2. George Poulett Scrope, Memoir on the Geology of Central France; Including the Volcanic Formations of Auvergne, The Velay, and the Vivarais (London, 1827), 165.

3. Scrope, 165. Both Stephen Jay Gould (Time's Arrow, Time's Cycle: Myth and Metaphor in the Discovery of Geological Time [Cambridge, Mass., 1988]) and Martin J. S. Rudwick (Earth's Deep History: How It Was Discovered and Why It Matters [Chicago, 2014]) compare the significance of the geological discovery of "deep time" to the Copernican revolution.

4. Scrope, 165. See Henry Fielding, Tom Jones [1749], ed. John Bender and Simon Stern (Oxford, 1996), 68.

5. Tita Chico, "Three Times," Los Angeles Review of Books (July 23, 2019). See also Jessica Riskin, The Restless Clock: A History of the Centuries-Long Argument Over What Makes Living Things Tick (Chicago, 2018); Christina Lupton, Reading and the Making of Time in the Eighteenth Century (Baltimore, 2018); and Amit S. Yahav, Feeling Time: Duration, the Novel, and Eighteenth-Century Sensibility (Philadelphia, 2018).

6. See E. P. Thompson, "Time, Work-Discipline, and Industrial Capitalism," Past $\mathcal{E}$ Present 38 (1967): 56-97.

7. Karol Berger, Bach's Cycle, Mozart's Arrow: An Essay on the Origins of Musical Modernity (Berkeley and Los Angeles, 2007), 14. Michael Spitzer similarly conceives of the movement from Baroque to Classical composition as inherently temporal: "Classical form, with its aurally transparent functional differentiation between beginnings, middles, and endings, can be as predictable as a rhythmic pattern. We know where we are in a sonata, in a way that is not possible in the less conventionalized forms of the baroque" (Metaphor and Musical Thought [Chicago, 2015], 213).

8. Berger, 9 .

9. On this temporal movement, see especially Sean Shesgreen, Hogarth and the Timesof-the-Day Tradition (Ithaca, 1983).

10. Ian R. Watt, The Rise of the Novel: Studies in Defoe, Richardson, and Fielding, 2nd ed. (Berkeley and Los Angeles, 2001), 22.

11. On the consequentialism of Daniel Defoe, Samuel Richardson, and Fielding, see Sandra Macpherson, Harm's Way: Tragic Responsibility and the Novel Form (Baltimore, 2010). On Jane Austen, see Macpherson, "Rent to Own; or, What's Entailed in Pride and Prejudice," Representations, 82 no. 1 (2003): 1-23.

12. Many have followed Dorothy Van Ghent's comparison of Fielding's art to Andrea Palladio's: "We may think of Tom Jones as a complex architectural figure, a Palladian palace perhaps" (The English Novel, Form and Fiction [New York, 1953], 80). 
13. Roger Matthew Grant, Beating Time and Measuring Music in the Early Modern Era (Oxford, 2014), 2.

14. See Thompson; David Landes, Revolution in Time (Cambridge, Mass., 1983); and Stuart Sherman, Telling Time: Clocks, Diaries, and English Diurnal Form, 1660-1785 (Chicago, 1996).

15. According to Walter Benjamin, history develops through two competing senses of time: the first sense emphasizes historical time as uniform and progressive (described by Benjamin as "empty, homogeneous time"), while the second sense emphasizes time as ruptural and revolutionary (the "messianic" time of the here-and-now, or Jetztzeit); see "Theses on the Philosophy of History," in Illuminations, ed. Hannah Arendt, trans. Harry Zohn (New York, 1968), 253-64.

16. Isaac Newton, The Principia [1687], trans. I. Bernard Cohen and Anne Whitman (Berkeley and Los Angeles, 1999), 408.

17. William Holder distinguishes between "Original Measures of Time" (as created by celestial motions) and the "Secondary Measure of Time," referring to the human experience of these durations (and described by words like "day," "month," and "year") in A Discourse Concerning Time, 2nd ed. (London, 1701), 11. James Hodgson similarly writes, "Absolute, True, and Mathematical Time, considered in itself, or in its own Nature, without Relation to any external Being, flows equally or uniformly, and is otherwise called Duration; to distinguish it from Relative, Apparent, and Vulgar Time, which is a sensible external Measure of Duration by Motion; and this is what Astronomers, Chronologers, \&c. mean by the Word Time" (An Introduction to Chronology [London, 1747], 59).

18. Daniel Rosenberg and Anthony Grafton, Cartographies of Time: A History of the Timeline (Princeton, 2010), 19.

19. See, for example, Joseph Justus Scaliger, De Emendatione Temporum (Paris, 1583); and James Ussher, Annales Veteris Testamenti, a Prima Mundi Origine Deducti (London, 1650).

20. Julia Kristeva, “Women's Time," trans. Alice Jardine and Harry Blake, Signs 7, no. 1 (Autumn 1981): 13-35, 16.

21. Michel Serres, with Bruno Latour, Conversations on Science, Culture, and Time, trans. Roxanne Lapidus (Ann Arbor, 1996), 58.

22. Kristeva, 16.

23. Johannes Fabian, Time and the Other: How Anthropology Makes Its Object (New York, 2002).

24. Murray G. H. Pittock summarizes the extent and influence of the Scottish Enlightenment historiography: "The historiography of the Scottish Enlightenment has had an unparalleled influence on the way history has been understood in the United Kingdom, North America and throughout the erstwhile British Empire. It is to the Enlightenment that we owe the ideas of historical progress, of state development through time and ultimately, the whole teleological apparatus which for many years sustained what was known as the school of Whig history: the analysis of the past not on its own terms, but in the light of what it could contribute to an account of progress towards the present" ("Historiography," in The Cambridge Companion to the Scottish Enlightenment, ed. Alexander Broadie [Cambridge, 2003], 258-79, 258).

25. Immanuel Kant, "What is Enlightenment?" [1784], in Basic Writings of Kant, ed. Allen W. Wood (New York, 2001), 133-42, 133. For the view of Enlightenment as a Bildungsroman, see Srinivas Aravamudan, Enlightenment Orientalism: Resisting the Rise of the Novel (Chicago, 2012), 1.

26. Here, for example, is Paul K. Alkon's authoritative assessment: "Most notable among these pioneering experiments with futuristic fiction is the first utopia set ahead in time rather than on some imaginary island: Louis-Sébastien Mercier's widely read L'An 2440 (The Year 2440), a utopian vision of twenty-fifth century Paris"' (Science Fiction Before 1900: Imagination Discovers Technology [New York and London, 2002], 21). 
27. Mercier, quoted in Robert Darnton, The Forbidden Best-Sellers of Pre-Revolutionary France (London, 1996), 125.

28. See Reinhart Koselleck, Futures Past: On the Semantics of Historical Time, trans. Keith Tribe (Cambridge, Mass., 1985); Emily Rohrbach: Modernity's Mist: British Romanticism and the Poetics of Anticipation (New York, 2015); Anahid Nersessian, Utopia, Limited: Romanticism and Adjustment (Cambridge, Mass., 2015); and Jonathan Sachs, The Poetics of Decline in British Romanticism (Cambridge, 2018).

29. See Eric Gidal, Ossianic Unconformities: Bardic Poetry in the Industrial Age (Charlottesville, 2015); and Tobias Menely, “'The Present Obfuscation': Cowper's Task and the Time of Climate Change," PMLA 127, no. 3 (2012): 477-92.

30. Menely, 489.

31. On the tradition of poetic prophecy, see especially Ian Balfour, The Rhetoric of Romantic Prophecy (Stanford, 2003). On the development of scientific prediction and the new calculus of chance, see especially Ian Hacking, The Emergence of Probability (Cambridge, 2006); and Lorraine Daston, Classical Probability in the Enlightenment (Princeton, 1995). 
Copyright of Eighteenth Century: Theory \& Interpretation (University of Pennsylvania Press) is the property of University of Pennsylvania Press and its content may not be copied or emailed to multiple sites or posted to a listserv without the copyright holder's express written permission. However, users may print, download, or email articles for individual use. 